\title{
Parents' perspectives toward young children being famous in the social media
}

\author{
Allehyani, Sabha Hakim \\ Department of Kindergarten, Umm Al-Qura University, Saudi Arabia \\ Mohandis, Maisa Yousef \\ Department of Kindergarten, Umm Al-Qura University, Saudi Arabia
}




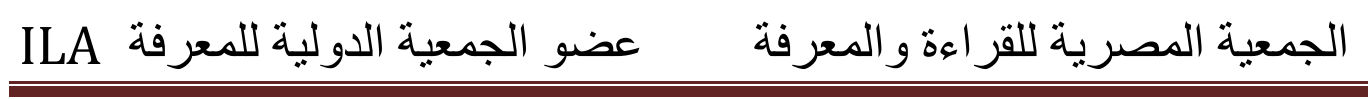




\title{
الجمعية المصرية للقر اعة والمعرفة عضو الجمعية الدولية للمعرفة ILA
}

\begin{abstract}
Background: In recent years, social media has become ubiquitous and important for social networking and content sharing. In this study, we demonstrate how social media can be used by children to be famous. This study aims to evaluate the use of social media by children to be famous; this study is designed to view parents' attitudes about using the social media by young children. Method: participants were 135 parents from the Kingdom of Saudi Arabia. The participants were selected randomly. Results: The results from this study revealed that most of parents would like to see their children famous to be part of the group in the society only, and most of parents analyzed the reason why their children seeking fame because children were being bullied before.
\end{abstract} Conclusions/significance: This study is reviewing parents' perspectives with using social media by children to be famous in Saudi Arabia. The findings from this study reveal the parents' perspectives toward the fame of their children, and illustrating why some parents would like to see their children famous, the finding of this study stated that children seeking fame to satisfy their ego gratification. Implementation: As children grow parents should be close to children, trying to make them their friends, to understand their needs to be famous in an attempt to try to save them from running behind the specter of fame.

Keywords: social media, fame, famous

\section{Introduction:}

Apparently the days are over when children wanted to grow up to be astronauts or policemen or firemen, now they want to be actors, singers or YouTube personalities. The role and influence of celebrity in our society is huge, and evidence suggests that many individuals show a desire for fame, Further, we are living in a cultural moment in which ostensibly anyone can achieve sudden fame via the latest reality television show or YouTube.com video (YouGov, 2006).

Social Networks have become an integral part of today's Web; such a global integration of social media into everyday life is rapidly becoming the norm, and arguably is here to stay (Boyd, 2009). 
In many cases, children spend more time with media than they do with their parents or in school (Gunn \& Donahue, 2008). Social media affords myriad opportunities to feel seen and admired; it is not surprising that scholars have identified both self-presentation and belonging needs as primary motivations for using FB (Nadkarni \& Hofmann, 2012).

As such, media are a significant socialization force with connections to salient developmental tasks in early adolescence such as social learning and identity formation (Subrahmanyam \& Smahel, 2010).

Further, it was speculated that superficial and self-oriented social media use may explain, in part, an observed decline in self-reported empathy among college students over the past several decades (Konrath et al., 2011).

Thus, Past research found that messages in popular television promote fame as a top value, while social media allow anyone to reach broad audiences (Uhls \& Greenfield, 2012).

Not everyone would be interested in appearing on a reality television show for an opportunity to become famous but it does appear that there is a collective belief that being famous is an important and worthwhile goal that would contribute to a meaningful and fulfilling life (Uhls \& Greenfield, 2012).

The desire for fame and celebrity is increasing and many exhibit this desire believing that they will achieve it, the global growth of the internet has been related to the desire for fame and makes it seem more easily attainable (Choi \& Berger, 2009).

Today and for many people, attention to pseudo-events and the manufactured mass media products of fame and heroes have replaced interest in real events, people and lives (Halpern, 2007).

when people feel frustrated by the lack of material achievement associated with the rich and famous, they develop they develop a psychological condition known as achievement famine, this condition leads to the desire for fame as a route to fulfilling one's desires (Rojek, 2001). 


\section{الجمعية المصرية للقر اعة والمعرفة عضو الجمعية الدولية للمعرفة ILA}

a study conducted by Uhls and Greenfield (2012) found that $40 \%$ of 10-12year-old children report fame as their number one goal in life (benevolence and achievement fell into the second and third positions, respectively) for reasons that include attention, money, and popularity.

And the study of Amy Noser \& Virgil Zeigler-Hill (2014) the goal of this study was to gain a more nuanced understanding of the relationship that exists between self-esteem and the desire to be famous.

And the study of Maltby et al. (2008): The aim of the present studies was to generate implicit theories of a desire for fame among the general population.

Also, The study of Maltby (2010): examined the relationship between an interest in fame and measures of the five-factor model of personality, narcissism, selfesteem, curiosity, attachment style and perceived family, and peer and media influence.

The study of Dara Greenwood (2013): seeks to clarify how specific views of self are associated with specific dimensions of fame appeal.

The study of Gountas et al. (2012): aims to test the relationships between the desire for fame and intrinsic and extrinsic goals and aspirations, specifically, a stronger desire for fame is predicted to correlate positively with extrinsic goals and aspirations (material achievement, social recognition etc.) and correlate negatively with intrinsic goals and aspirations (self-acceptance and affiliation).

\section{Theoretical framework}

Online social networking sites have become a core feature of daily life, with millions of social interactions being played out in the virtual space on a daily basis (Wilson, Gosling, \& Graham, 2012).

Children under 13 are not allowed to use most of social media without a parent's permission. However, one survey found that seven million children under the age of 13 have Facebook profiles, with five million of these under 10 years (Consumer Reports, 2011). 


\section{الجمعية المصرية للقراءة والمعرفة عضو الجمعية الدولية للمعرفة المي}

Social Networks such as Facebook and Twitter have far exceeded the traditional networking service of connecting people together. With millions of users actively using their platforms, social networks have attracted third parties who exploit them as an effective media to reach and potentially influence a large and diverse population of web users (A. M. Kaplan and M. Haenlein, 2010).

The extraordinary amount of time people spend on FB may be a reflection of its ability to satisfy ego needs that are fundamental to the human condition, that pertain to how people wish to see themselves-socially attractive and embedded in a network of meaningful relationships (Toma and Hancock, 2013).

Specifically, individuals may use social media in the service of ostensibly gratifying specific psychological needs - the need to feel seen and valued, and to feel meaningfully embedded in social networks. These needs may also manifest in individuals' attitudes about the appeal of fame, from being literally seen and admired, to having elite access to resources, to having the power and ability to help others (Dara N. Greenwood, 2013).

Additionally, research suggests that both fame and social media are more appealing among younger individuals (Uhls \& Greenfield, 2012). Psychologists have noted that in addition to a growth in entertainment media content that focuses on personal achievement and competition (e.g., reality TV shows), the ubiquitous invitation to post, tweet, and broadcast the self en masse via personalized new technologies may both reflect and fuel a societal shift toward individualistic values and a quest for fame (Konrath, O’Brien, \& Hsing, 2011).

A desire to differentiate one-self from others is an essential component of fame and a recognized factor in individualism (Maltby, 2010). As well as distracting individuals from the achievement of more intrinsic goals (e.g., self-acceptance) that are associated with personal growth and well-being (Vonk \& Smit, 2012).

Children who pursue extrinsic aspirational goals may be suffering emotional insecurity and general neuroticism perhaps because of social and economic disadvantages, In addition, recent empirical examinations of fame have found a number of different motivations for desiring fame that extend beyond a desire for acceptance, For example, extrinsic motivations such as financial success, 


\section{الجمعية المصرية للقر اعة والمعرفة عضو الجمعية الدولية للمعرفة ILA}

attractiveness, and social recognition are often associated with the desire to become famous (Gountas et al., 2012).

Many think of 'fame' as something earned, or merited, through exceptional deeds, on the other hand, it has long been acknowledged that one may achieve fame as a result of socially unacceptable or immoral behavior. Moreover, being famous requires extreme attention to image in order to capture the interest of audiences that can number in the multi-millions (Braudy, 1997).

These processes, he argues, have caused ordinary people to experience achievement famine, a concept referring to a 'psychological condition that results from frustrated desires for material and romantic achievement of the sort the rich and famous enjoy' (Rojek, 2001).

It was found that while some children's interest in celebrities was related to secure attachments and friendship groups, other children's interest in celebrities were related to avoidance attachment and poor relationship with their parents, reflecting more problematic aspects of the transition towards adulthood (Giles and Maltby, 2004).

In 2006, national kids day asked children under 10 years old to reveal their Christmas wish list, and the desire to be famous or achieve celebrity emerged at top of the list, followed by good looks and wealth, for these young people fame appears to be an aspiration or a goal (Johnson \& McSmith, 2006).

Also, a survey for the Association of Teachers and Lecturers found that $60 \%$ of teachers questioned felt that their pupils most aspired to be like David Beckham, and that $32 \%$ said their pupils modeled themselves on Paris Hilton (Pattinson, 2008).

And other experimental research on terror management theory has shown that one motive for desiring fame in the belief that one will be remembered after death (Greenberg, et al., 2010)

There is more to the fame and social media story than superficial values and self-involvement, however. Research suggests that both may also be fueled by 


\section{الجمعية المصرية للقر اءة والمعرفة عضو الجمعية الدولية للمعرفة ILA}

basic, even existential anxieties about the self. Prior analyses found that individuals with heightened inclusion anxiety (i.e., higher need to belong) showed increased interest in diverse appeals of fame, in addition to increased time spent engaged in fame fantasies (Greenwood et al., 2013).

Finally, such success, with apparently little effort, appeals to some who are also motivated by material success. Therefore, it is hardly surprising that fame is highly desired in "ordinary, everyday culture in modern times" (Rojek, 2001).

We expected that age might be inversely related to fame interest and narcissism, both of which have been found to be prevalent or salient for younger generations (Foster et al., 2003).

\section{Definitions}

Social Networks: We define social network sites as web-based services that allow individuals to construct a public or semi-public profile within a bounded system, articulate a list of other users with whom they share a connection, and view and traverse their list of connections and those made by others within the system (Boyd \& Ellison, 2007).

\section{Procedural definition}

Social media is the collective of online communications channels dedicated to community-based input, interaction, content-sharing and collaboration, Websites and applications dedicated to forums, micro blogging, social networking, social bookmarking and wikis are among the different types of social media.

\section{Methods}

\section{Research problem}

Study intended to answer the main question what is the adults' opinions about using social media by children to be famous? So this study intended to answer the following questions:

What draws children to be seeking fame?

How social media could help children being famous easily?

How and why children want to be famous?

\section{The Significance of this research}

This study is investigating adults' perspectives with using social media by children to be famous in Saudi Arabia which studied this issue in order to 


\section{الجمعية المصرية للقراءة والمعرفة عضو الجمعية الدولية للمعرفة ILA}

a)Raising the awareness of parents about the dangerous of children seeking fame and making fame their ultimate goal; b) defining fame appeal and its negative effects on children in an attempt.

\section{The aims of this research:}

The aims of this research:

1) To identify the reasons why the child is seeking fame.

2) To define the disadvantages of seeking fame and the negative effect of making the fame is the child's first goal.

3) To identify the methods used by the child to achieve fame.

\section{Participants}

Research sample formed from 135 parents, and they were selected randomly from the Kingdom of Saudi Arabia.

\section{Instrument}

The questionnaire has 13 main items (themes) which investigated participants" children gender, marital status, education, age, family size, children ages, household average salary, social network sites, beliefs about the fame of children, parents' perspectives about seeing their child famous, parents' attitude toward seeking fame, parents concepts about fame, children behavioral problem of being famous which the parents think affect the child negatively.

\section{Results}

The following is a comprehensive presentation of the results shown in Tables (1

- 13) and Figures $(1-13)$ in terms of:

\section{1- child's gender:}

Table (1) the distribution of the participants' according to child's gender

\begin{tabular}{|c|c|c|}
\hline Gender of your child & Number & Percentage \\
\hline \hline Boy & 51 & $37.8 \%$ \\
\cline { 2 - 3 } Girl & 84 & $62.2 \%$ \\
\hline \hline Sum & 135 & $100 \%$ \\
\hline
\end{tabular}




\section{الجمعية المصرية للقر اعة والمعرفة عضو الجمعية الدولية للمعرفة}

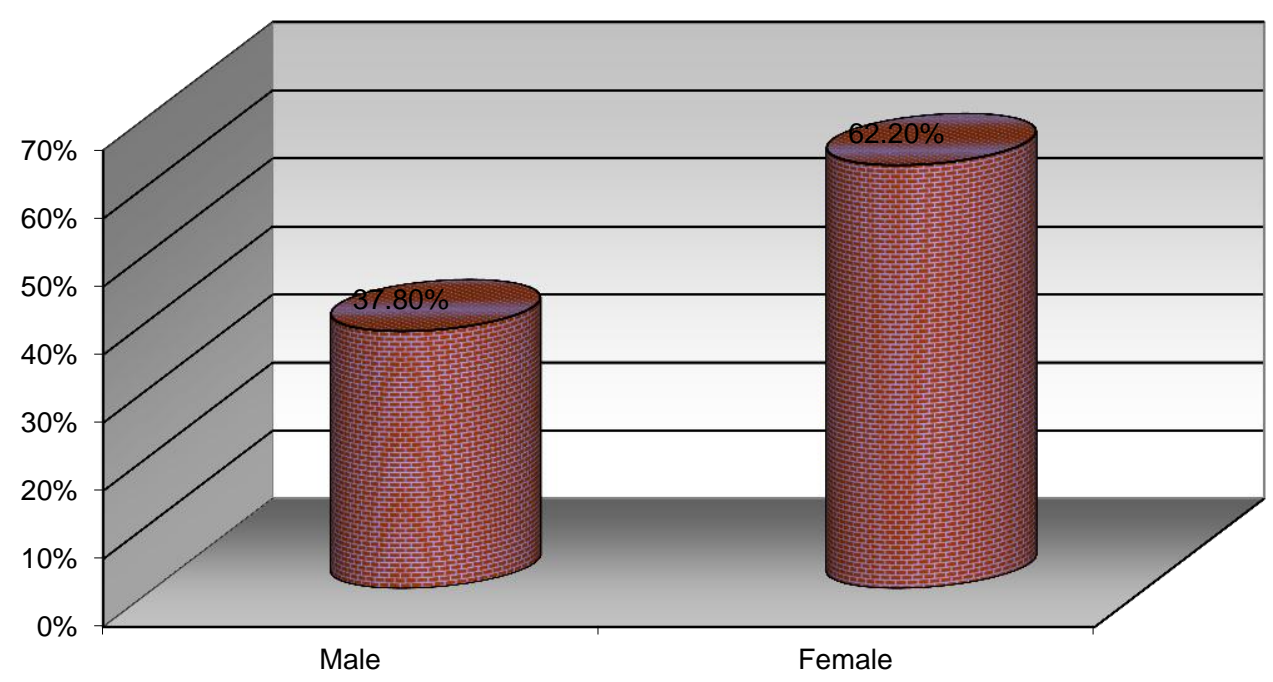

Figure (1) the distribution of the participants' according to child's gender

As shown in table (1), and figure (1) the distribution of the research sample according to the child's gender variable, showed that a total of 84 of the children is girls with a percentage $62.2 \%$, while 51 of the children were boys with a percentage $37.8 \%$

\section{2- Parent's marital status:}

Table (2) the distribution of the participants' according to parent's marital status

\begin{tabular}{|c||c||c|}
\hline Your Status & Number & Percentage \\
\hline \hline Married & 92 & $68.1 \%$ \\
\cline { 2 - 3 } Divorced & 26 & $19.3 \%$ \\
\hline Single parents & 17 & $12.6 \%$ \\
\hline \hline Sum & 135 & $100 \%$ \\
\hline
\end{tabular}


الجمعية المصرية للقر اعة والمعرفة عضو الجمعية الدولية للمعرفة ILA

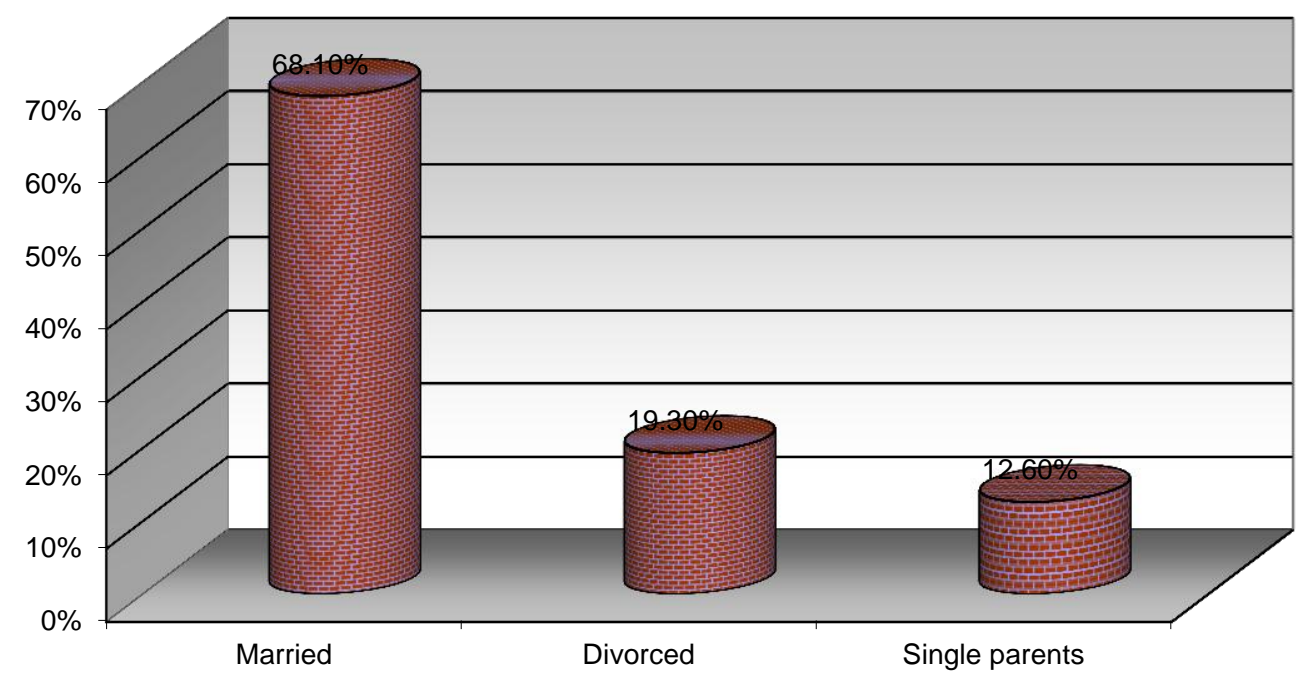

Figure (2) the distribution of the participants' according to parent's marital status

As shown in table (2), and figure (2) the distribution of the research sample according to the parent's marital status variable, showed that a total of 92 of the sample is married with a percentage $68.1 \%$, then 26 of the sample were divorced with a percentage $19.3 \%$, while 17 of the sample were single parents with a percentage $12.6 \%$.

\section{3- Parent's Age:}

Table (3) the distribution of the participants' according to parent's age

\begin{tabular}{|c|c|c|}
\hline Your Age & Number & Percentage \\
\hline \hline Up to 25 years old & 19 & $14.1 \%$ \\
\hline $26-39$ years old & 42 & $31.1 \%$ \\
\hline $40-49$ years old & 36 & $26.7 \%$ \\
\hline 50-59 years old & 23 & $17 \%$ \\
\hline Over 60 & 15 & $11.1 \%$ \\
\hline Sum & 135 & $100 \%$ \\
\hline \hline \multicolumn{2}{|l}{}
\end{tabular}




\section{الجمعية المصرية للقر اعة و المعرفة عضو الجمعية الدولية للمعرفة}

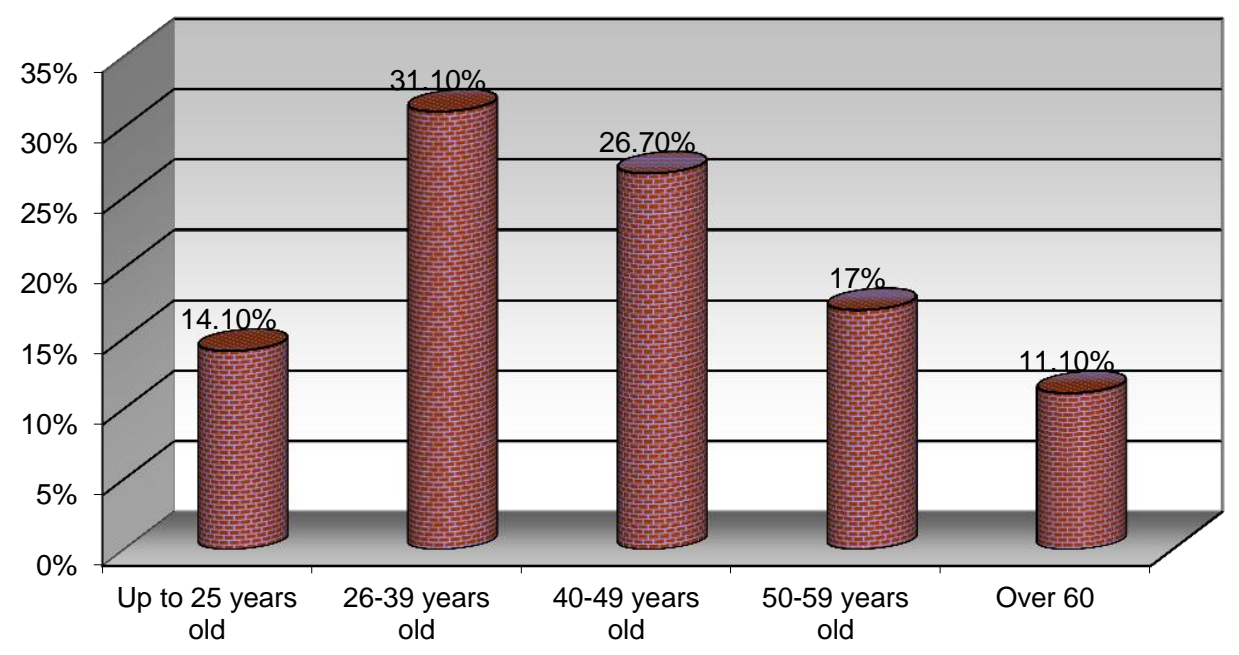

Figure (3) the distribution of the participants' according to parent's age

Table (3) and figure (3) displayed the distribution of the participants' according to parent's age, A total of 42 of the research sample ages were $26-39$ years with a percentage $31.1 \%$, followed by 36 of the research sample ages were $40-$ 49 years with a percentage $26.7 \%$, Then In the third place 23 of the research sample ages were $50-59$ years with a percentage $17 \%$, in the fourth place 19 of the research sample ages were up to 25 years with a percentage $14.1 \%$, and finally 15 of the research sample ages were over 60 years with a percentage $11.1 \%$.

\section{4- Family size:}

Table (4) the distribution of the participants' according to the family size

\begin{tabular}{||c|c|c|}
\hline Family size & Number & Percentage \\
\hline \hline Small family (5-7 members) & 68 & $50.4 \%$ \\
\cline { 2 - 3 } $\begin{array}{c}\text { Big family (8-10 members) live } \\
\text { independently }\end{array}$ & 40 & $29.6 \%$ \\
\hline $\begin{array}{c}\text { Big family (0ver 10 members) live with } \\
\text { grandparents }\end{array}$ & 27 & $20 \%$ \\
\hline \hline Sum & 135 & $100 \%$ \\
\hline
\end{tabular}




\section{الجمعية المصرية للقراعة والمعرفة عضو الجمعية الدولية للمعرفة ILA}

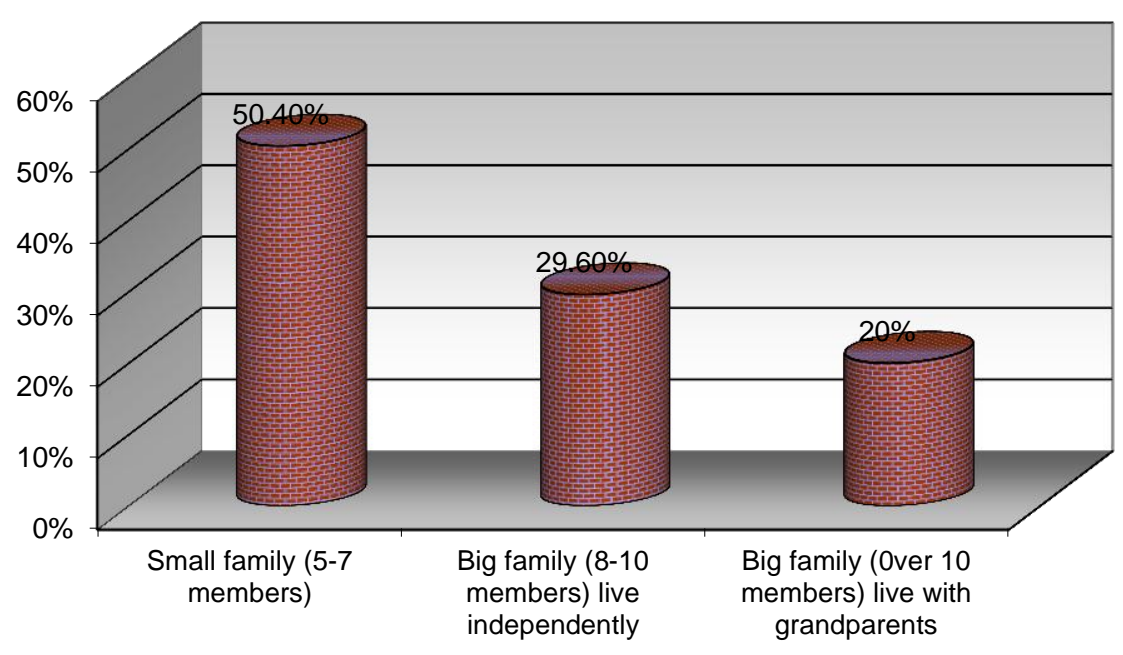

Figure (4) the distribution of the participants' according to the family size

Table (4) and figure (4) illustrated the distribution of the research sample according to the family size variable, showed that a total of 68 of the sample were live in small families $(5-7)$ members with a percentage $50.4 \%$, then 40 of the sample were live in big families $(8-10)$ members with a percentage $29.6 \%$, while 27 of the sample were live in big families (over 10 members) with a percentage $20 \%$.

\section{5- Parent's level of education:}

Table (5) the distribution of the participants' according to Parent's level of education

\begin{tabular}{|c|c|c|}
\hline What is your level of education & Number & Percentage \\
\hline \hline Completed primary & 16 & $11.9 \%$ \\
\hline Completed High school & 25 & $18.5 \%$ \\
\hline Diploma & 30 & $22.2 \%$ \\
\hline Bachelor degree & 56 & $41.5 \%$ \\
\hline Higher education ((Master -Doctorate) & 8 & $5.9 \%$ \\
\hline \hline Sum & 135 & $100 \%$ \\
\hline
\end{tabular}




\section{الجمعية المصرية للقراءة والمعرفة عضو الجمعية الدولية للمعرفة ILA}

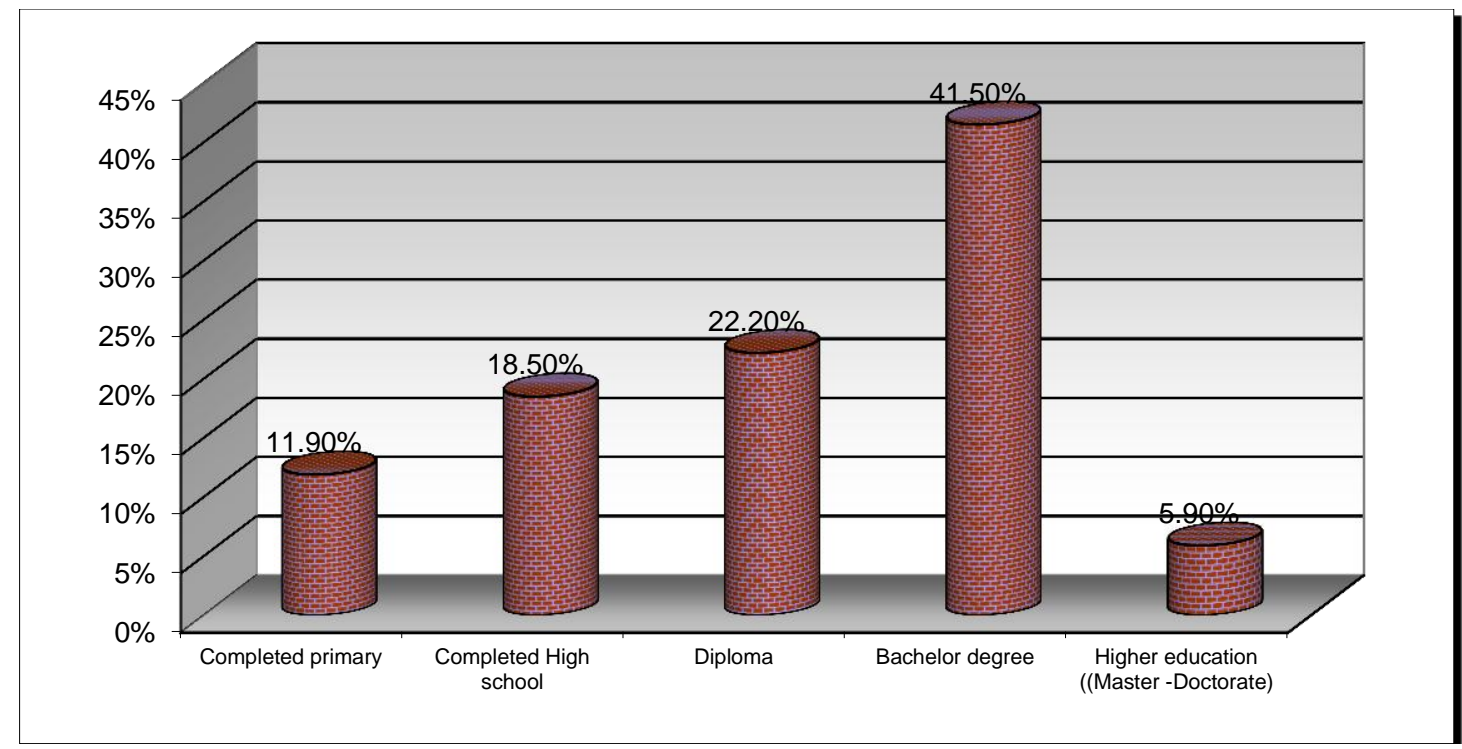

Figure (5) the distribution of the participants' according to Parent's level of education

As shown in Table (5) and figure (5) a total of 56 of the research sample have Bachelor degree with a percentage $41.5 \%$, followed 30 of the research sample have Diploma with a percentage $22.2 \%$, Then in the third place 25 of the research sample have completed high school with a percentage $18.5 \%$, Around $11.9 \%$ of the sample $(n=16)$ have completed primary, finally 8 of the research sample have Higher education (Master - Doctorate) with a percentage 5.9\%.

\section{6- parent's average household salary per month:}

Table (6) the distribution of the participants' according to Parent's average salary

\begin{tabular}{|c||c|c|}
\hline $\begin{array}{c}\text { What is your average household } \\
\text { salary per month? }\end{array}$ & Number & Percentage \\
\hline \hline Less than-4000SR & 12 & $8.9 \%$ \\
\hline 9000-4,000SR & 18 & $13.3 \%$ \\
\hline $15,000-10,000 S R$ & 27 & $20 \%$ \\
\hline 30,000-20, 000 SR & 42 & $31.1 \%$ \\
\hline More than 40,000SR & 36 & $26.7 \%$ \\
\hline Sum & 135 & $100 \%$ \\
\hline \hline
\end{tabular}




\section{الجمعية المصرية للقر اءة و المعرفة عضو الجمعية الدولية للمعرفة}

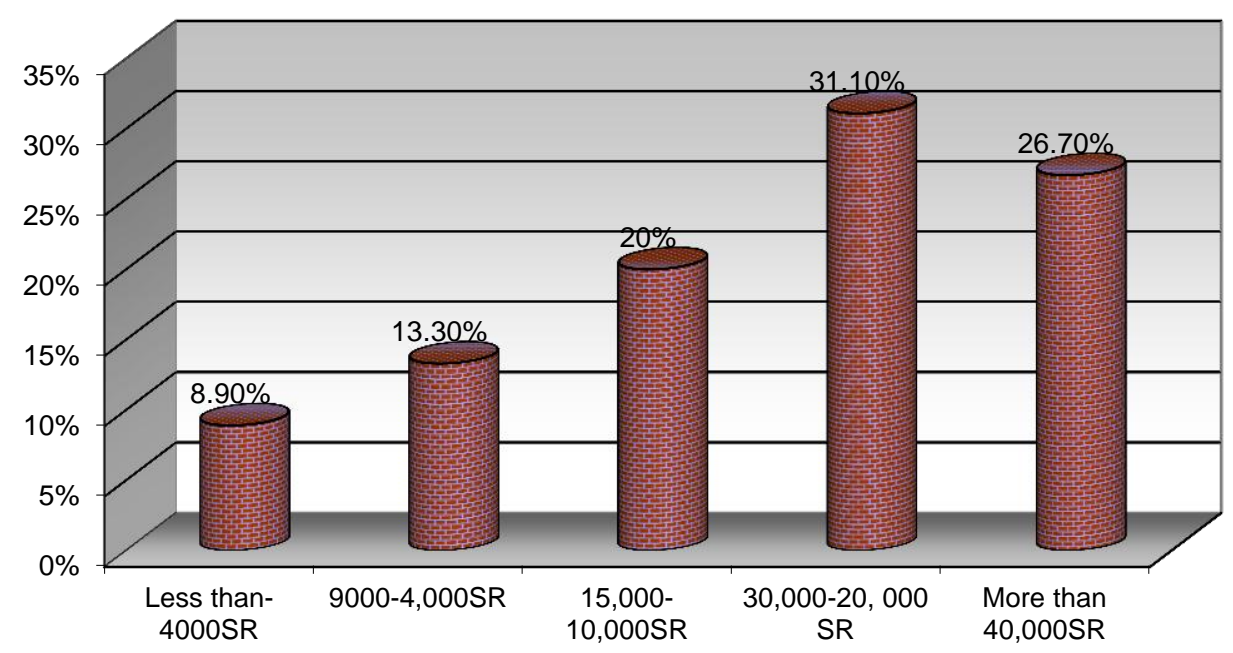

Figure (6) the distribution of the participants' according to Parent's average salary

Table (4) and figure (4) illustrated the distribution of the research sample according to the parent's average salary variable, showed that a total of 42 of the sample were having ( $20.000-30.000 \mathrm{SR})$ with a percentage $31.1 \%$, then 36 of the sample were having more than 40.000 SR with a percentage $26.7 \%$, followed by 27 of the sample having $(10.000-15.000 \mathrm{SR})$ with a percentage $20 \%$, then 18 of the sample having $(4.000-9.000$ SR) with a percentage $13.3 \%$, while finally 12 of the sample having less than 4000 SR with a percentage $8.9 \%$.

\section{7- child's Age:}

Table (7) the distribution of the participants' according to child's age

\begin{tabular}{|c|c||c|}
\hline How old your child & Number & Percentage \\
\hline 0- 1 year & 6 & $4.4 \%$ \\
\hline 2-3 years & 15 & $11.1 \%$ \\
\hline 4-5 years & 40 & $29.6 \%$ \\
\hline 6-7 years & 53 & $39.3 \%$ \\
\hline 8-9years & 21 & $15.6 \%$ \\
\hline \hline Sum & 135 & $100 \%$ \\
\hline
\end{tabular}




\section{الجمعية المصرية للقر اءة والمعرفة عضو الجمعية الدولية للمعرفة ILA}

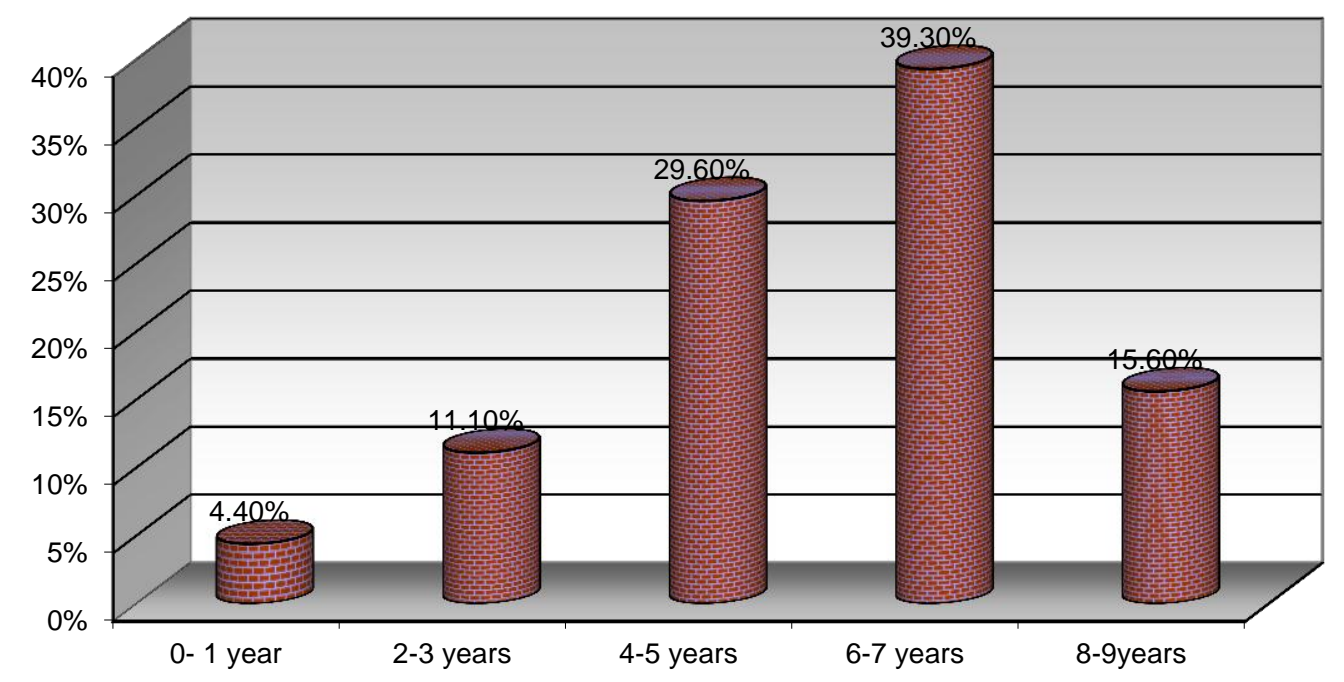

Figure (7) the distribution of the participants' according to child's age

As shown in Table (7) and figure (7) the distribution of the research sample according to the child's age variable showed that a total of 53 of the research sample their ages were 6-7 years with a percentage $39.3 \%$, followed by 40 of the research sample their ages were 4-5 years with a percentage $29.6 \%$, Then 21 of the research sample their ages were 8-9 years with a percentage $15.6 \%$, followed by 15 of the research sample their ages were $2-3$ years with a percentage $11.1 \%$, Then finally 6 of the research sample their ages were 0-1 years with a percentage $4.4 \%$.

\section{8- the social network sites (SNS) used the most in everyday life by the child:}

Table (8) the distribution of the participants' according to the social networks sites used the most by the child

\begin{tabular}{|c|c|c|}
\hline $\begin{array}{c}\text { Which is the most social network } \\
\text { sites (SNS) does your child use in } \\
\text { their everyday life? }\end{array}$ & Number & Percentage \\
\hline What's APP & 102 & $26.8 \%$ \\
\hline Instagram & 44 & $11.5 \%$ \\
\hline Snapchat & 82 & $21.5 \%$ \\
\hline You Tube & 56 & $14.7 \%$ \\
\hline
\end{tabular}




\section{ILA الجمعية المصرية للقر اعة و المعرفة عضو الجمعية الدولية للمعرفة}

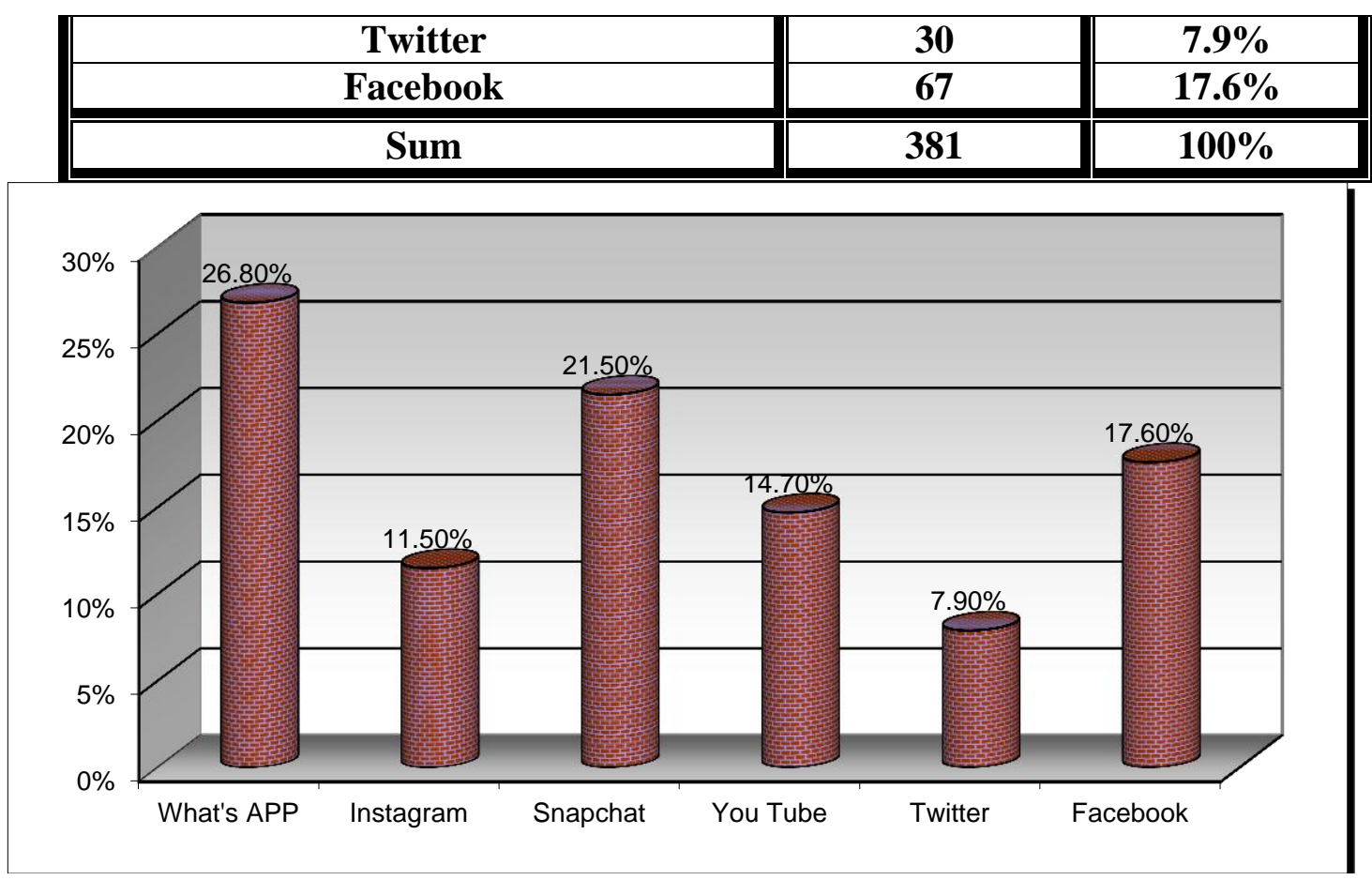

Figure (8) the distribution of the participants' according to the social networks sites used the most by the child

As shown in Table (8) and figure (8) showed that there were of 102 of the research sample were using whatsapp with a percentage $26.8 .3 \%$, followed by 82 of the research sample were using Snapchat with a percentage $21.5 \%$, Then 67 of the research sample were using Facebook with a percentage 17.6\%, followed by 56 of the research sample were using Youtube with a percentage $14.7 \%$, Then 44 of the research sample were using Instagram with a percentage 11.5 , finally 30 of the research sample were using Twitter with a percentage $7.9 \%$.

\section{9- Parental beliefs about the fame of children :}

Table (9) the distribution of the participants' according to Parental beliefs about the fame of children

\begin{tabular}{|c|c|c|}
\hline $\begin{array}{c}\text { Parental beliefs about the } \\
\text { fame of children }\end{array}$ & Number & Percentage \\
\hline \hline $\begin{array}{c}\text { My child would rather be famous than } \\
\text { smart }\end{array}$ & 14 & $10.4 \%$ \\
\hline Children who watch TV and read "glam & 21 & $15.6 \%$ \\
\hline
\end{tabular}


ILA الجمعية المصرية للقر اءة والمعرفة عضو الجمعية الدولية للمعرفة

\begin{tabular}{|c||c||c||}
\hline mags" want and expect fame the most & & \\
\cline { 2 - 3 } $\begin{array}{c}\text { Heavy TV-watchers are especially likely to } \\
\text { believe fame will improve their lives }\end{array}$ & 19 & $14.1 \%$ \\
\hline Poor children are more desperate for fame & 15 & $11.1 \%$ \\
\hline $\begin{array}{c}\text { Children who watch TV and read "glam } \\
\text { mags" want and expect fame the most }\end{array}$ & 10 & $7.4 \%$ \\
\hline $\begin{array}{c}\text { Heavy TV-watchers are especially likely to } \\
\text { believe fame will improve their lives }\end{array}$ & 8 & $5.9 \%$ \\
\hline $\begin{array}{c}\text { Lonely and depressed children hope that } \\
\text { fame will solve their problems }\end{array}$ & 17 & $12.6 \%$ \\
\hline $\begin{array}{c}\text { Lonely children are also more likely to } \\
\text { follow the lives of celebrities }\end{array}$ & 12 & $8.9 \%$ \\
\hline My life's ambition to have a famous child & 13 & $9.6 \%$ \\
\hline $\begin{array}{c}\text { Children believe that celebrities deserve } \\
\text { their fame }\end{array}$ & 6 & $4.4 \%$ \\
\hline \hline Sum & 135 & $100 \%$ \\
\hline
\end{tabular}

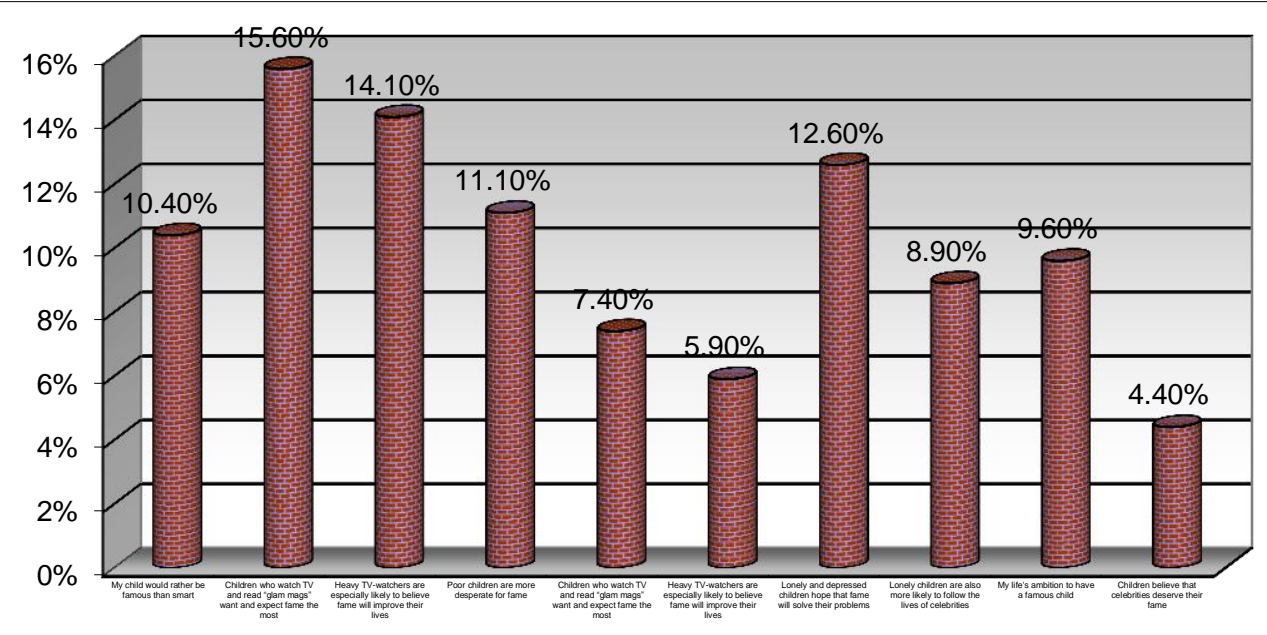

Figure (9) the distribution of the participants' according to Parental beliefs about the fame of children

Table (9) and figure (9) shows that 21 of the research sample indicated that "Children who watch TV and read "glam mags" want and expect fame the most" with a percentage $15.6 \%$, followed by 19 of the research sample reported that "Lonely and depressed children hope that fame will solve their problem" with a percentage $14.1 \%$. Around $12.6 \%(\mathrm{n}=17)$ reported that "Lonely and 
depressed children hope that fame will solve their problems", followed by 15 of the research sample said that "Poor children are more desperate for fame" with a percentage $11.1 \%$. A total of 14 of the research sample said that "My child would rather be famous than smart" with a percentage $10.4 \%$, followed by 13 of the research sample said that "My life's ambition to have a famous child" with a percentage $9.6 \%$, A total of 12 of the research sample reported that "Lonely children are also more likely to follow the lives of celebrities" with a percentage $8.9 \%$, followed by 10 of the research sample said that "Children who watch TV and read "glam mags" want and expect fame the most" with a percentage 7.4\%. Only 8 of the research sample reported that "Heavy TV-watchers are especially likely to believe fame will improve their lives" with a percentage $5.9 \%$, A few number of participants $(n=6)$ mentioned that "Children believe that celebrities deserve their fame" with a percentage $4.4 \%$.

This finding stated that most of the children watching TV will be wanting and seeking fame, influenced by some celebrities who see and desire in what available to them from luxuries.

\section{0- Parents' perspectives about seeing their child famous for any} reason:

Table (10) the distribution of the participants' according to parents' perspectives about seeing their child famous

\begin{tabular}{|c|c|c|}
\hline $\begin{array}{l}\text { Do you prefer to see your child } \\
\text { Famous for any reason? }\end{array}$ & Number & Percentage \\
\hline $\begin{array}{c}\text { I want to see my child's picture in } \\
\text { magazine }\end{array}$ & 26 & $19.3 \%$ \\
\hline $\begin{array}{l}\text { My child should be famous because of } \\
\text { his/her unique character }\end{array}$ & 15 & $11.1 \%$ \\
\hline $\begin{array}{l}\text { I want my child to be famous, so he/she } \\
\text { can contribute to society }\end{array}$ & 6 & $4.4 \%$ \\
\hline $\begin{array}{l}\text { I would do anything to my child to be } \\
\text { famous }\end{array}$ & 10 & $\mathbf{7 . 4 \%}$ \\
\hline $\begin{array}{l}\text { Being famous would bring some meaning } \\
\text { to my child's life }\end{array}$ & 7 & $5.2 \%$ \\
\hline $\begin{array}{l}\text { Parents should encourage their children to } \\
\text { be famous if their child wishes that }\end{array}$ & 21 & $15.6 \%$ \\
\hline Parents should give their child space of & 14 & $10.4 \%$ \\
\hline
\end{tabular}




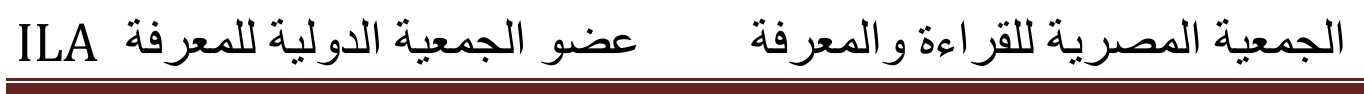

\begin{tabular}{|c|c|c|}
\hline $\begin{array}{l}\text { freedom to be famous, but they must } \\
\text { monitor their child's social behavior }\end{array}$ & & \\
\hline $\begin{array}{l}\text { Parents should ask/supervise the contents } \\
\text { of their child's online postings (on Social } \\
\text { Network Sites (SNS such as Snapchat, } \\
\text { Instagram, WhatsApp, YouTube) }\end{array}$ & 11 & $8.1 \%$ \\
\hline $\begin{array}{l}\text { Being famous in these days is important } \\
\text { for my child to have good future } \\
\text { (financially/socially) }\end{array}$ & 17 & $12.6 \%$ \\
\hline $\begin{array}{l}\text { Being famous may effected children' life } \\
\text { negatively as it prevents them from } \\
\text { enjoying their childhood }\end{array}$ & 8 & $5.9 \%$ \\
\hline Sum & 135 & $100 \%$ \\
\hline
\end{tabular}

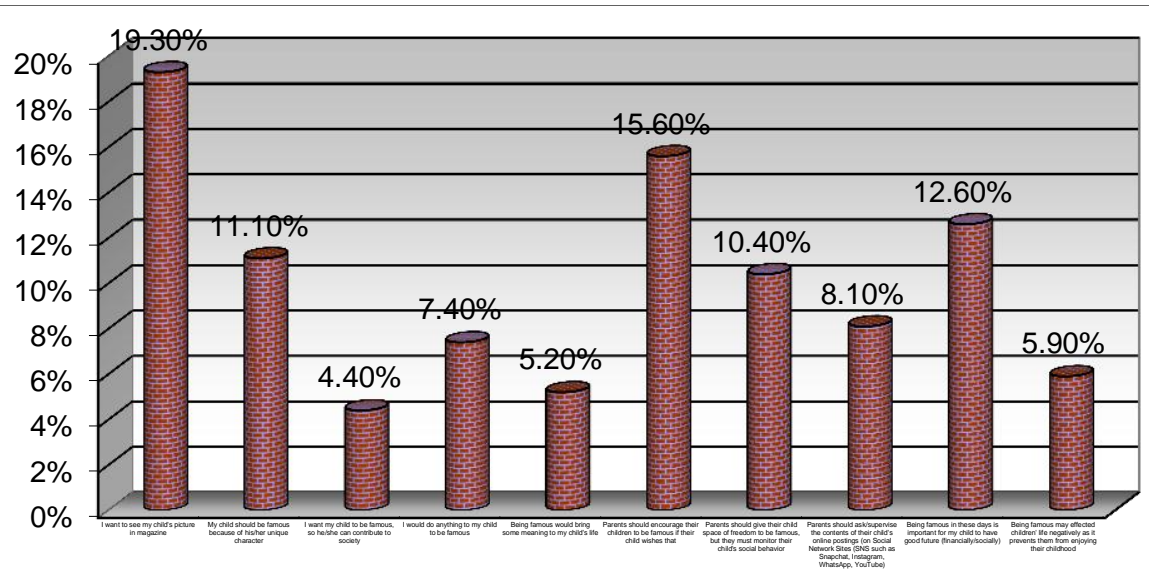

Figure (10) the distribution of the participants' according to parents' perspectives about seeing their child famous

Table (10) and figure (10) shows that 26 of the research sample indicated that "I want to see my child's picture in magazine" with a percentage $19.3 \%$, followed by 21 of the research sample reported that "Parents should encourage their children to be famous if their child wishes that" with a percentage $15.6 \%$. Around $12.6 \%(\mathrm{n}=17)$ reported that "Being famous in these days is important for my child to have good future (financially/socially)", followed by 15 of the research sample said that "My child should be famous because of his/her unique 
character" with a percentage $11.1 \%$. A total of 14 of the research sample said that "Parents should give their child space of freedom to be famous, but they must monitor their child's social behavior" with a percentage $10.4 \%$, followed by 11 of the research sample said that "Parents should ask/supervise the contents of their child's online postings (on Social Network Sites (SNS such as Snapchat, Instagram, WhatsApp, YouTube)" with a percentage $8.1 \%$, A total of 10 of the research sample reported that "I would do anything to my child to be famous" with a percentage $7.4 \%$, followed by 8 of the research sample said that "Being famous may effected children' life negatively as it prevents them from enjoying their childhood" with a percentage $5.9 \%$. Only 7 of the research sample reported that "Being famous would bring some meaning to my child's life" with a percentage $5.2 \%$, A few number of participants $(n=6)$ mentioned that "I want my child to be famous, so he/she can contribute to society" with a percentage $4.4 \%$.

\section{1- Parents' attitude toward seeking fame for their children}

Table (11) the distribution of the participants' according to parents' attitude toward seeking fame for their children

\begin{tabular}{|c||c||c|}
\hline $\begin{array}{c}\text { What do you think the most value } \\
\text { influence parents/children's } \\
\text { attitude to seek for future goals in } \\
\text { relation to Social Network Sites } \\
\text { (SNS)? }\end{array}$ & Number & Percentage \\
\hline \hline Fame itself (being famous) & 13 & $9.6 \%$ \\
\hline Benevolence (being kind to other) & 9 & $6.7 \%$ \\
\hline Community feeling (being part of the \\
group) & 32 & $23.7 \%$ \\
\hline Achievement (being successful) & 20 & $14.8 \%$ \\
\hline Financial success (being rich) & 15 & $11.1 \%$ \\
\hline Self-acceptance (looking good) & 21 & $15.6 \%$ \\
\hline Image (What you look like) & 25 & $18.5 \%$ \\
\hline \hline Sum & 135 & $100 \%$ \\
\hline
\end{tabular}




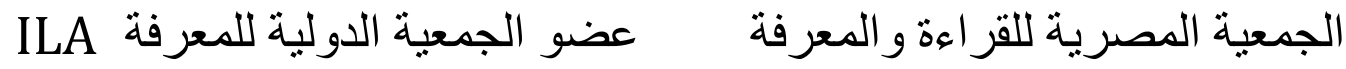

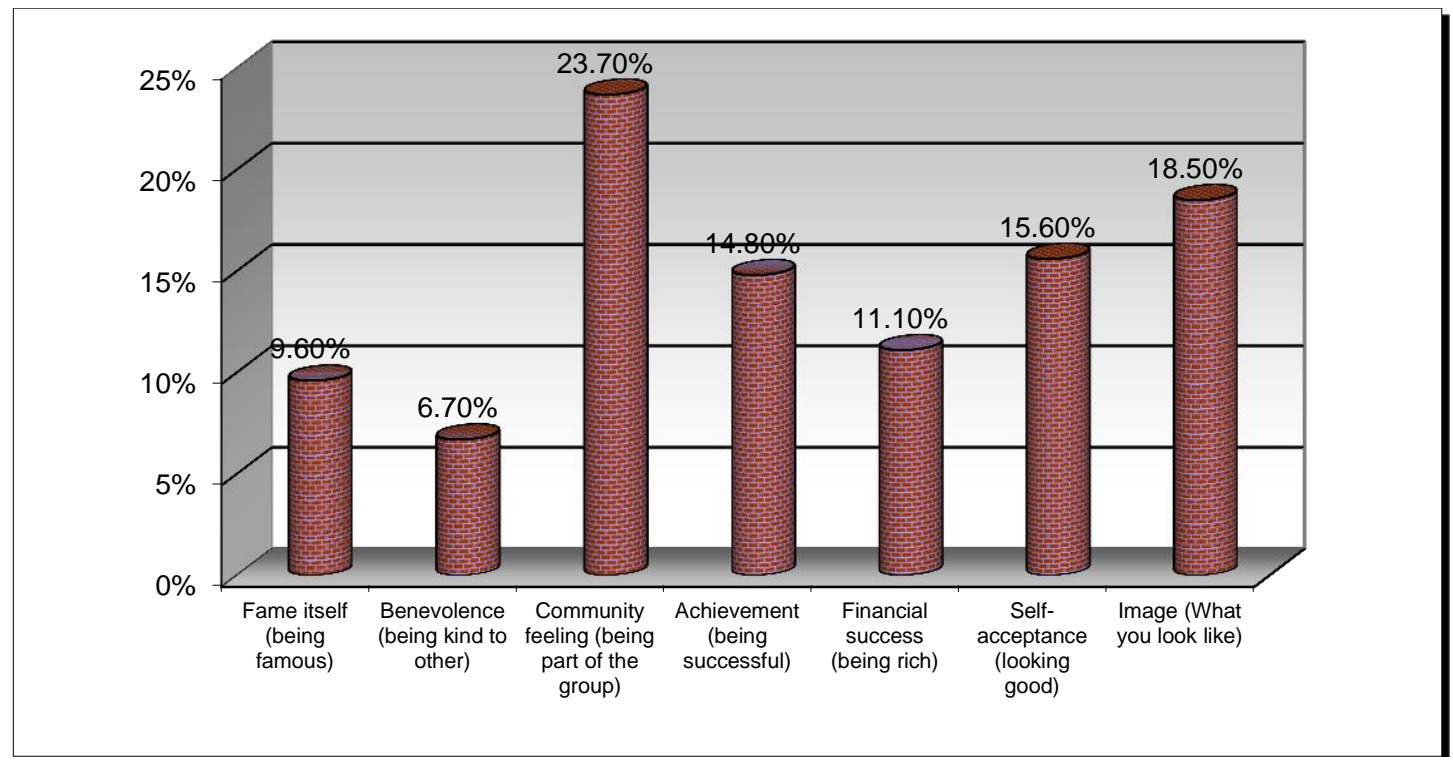

Figure (11) the distribution of the participants' according to parents' attitude toward seeking fame for their children

As shown in table (11) and figure (11) Most of the incidents that were reported community feeling (being part of the group) with a percentage $23.7 \%$, followed by 25 reported that Image (What you look like) with a percentage $18.5 \%$. Then 21 of the participants reported that Self-acceptance (looking good) with a percentage $16.6 \%$, while 20 of the research sample reported that Achievement (being successful) with a percentage $14.8 \%$. Then in the fifth place 15 of the research sample reported that Financial success (being rich) with a percentage $11.1 \%$, then 13 of the research sample reported that fame itself (being famous) with a percentage $9.6 \%$. Finally 9 of the research sample reported that Benevolence (being kind to other) with a percentage $6.7 \%$.

This finding state that your need to influence in your society, your belonging to it, and participation in its events, prompts you to seek fame through social networking sites that allow you to do so, as the Findings of the study of Dara Greenwood (2013) illuminate the socio-emotional underpinnings of fame appeal and the individual differences that may render certain aspects of fame particularly alluring, it is also found that both belongingness needs and narcissism were associated with multiple dimensions of fame appeal,

\section{2- Parent's concepts about the experience of fame}




\section{الجمعية المصرية للقر اءة والمعرفة عضو الجمعية الدولية للمعرفة ILA}

Table (12) the distribution of the participants' according to parents' concepts about the experience of fame

\begin{tabular}{|c|c|c|}
\hline $\begin{array}{c}\text { In which word could you describe } \\
\text { the life experience of being } \\
\text { famous? }\end{array}$ & Number & Percentage \\
\hline \hline Ego gratification & 47 & $34.8 \%$ \\
\hline Unlimited access to life luxurious life & 29 & $21.5 \%$ \\
\hline Enormous wealth & 31 & $22.9 \%$ \\
\hline adoration & 16 & $11.9 \%$ \\
\hline warmth & 12 & $8.9 \%$ \\
\hline Sum & 135 & $100 \%$ \\
\hline
\end{tabular}

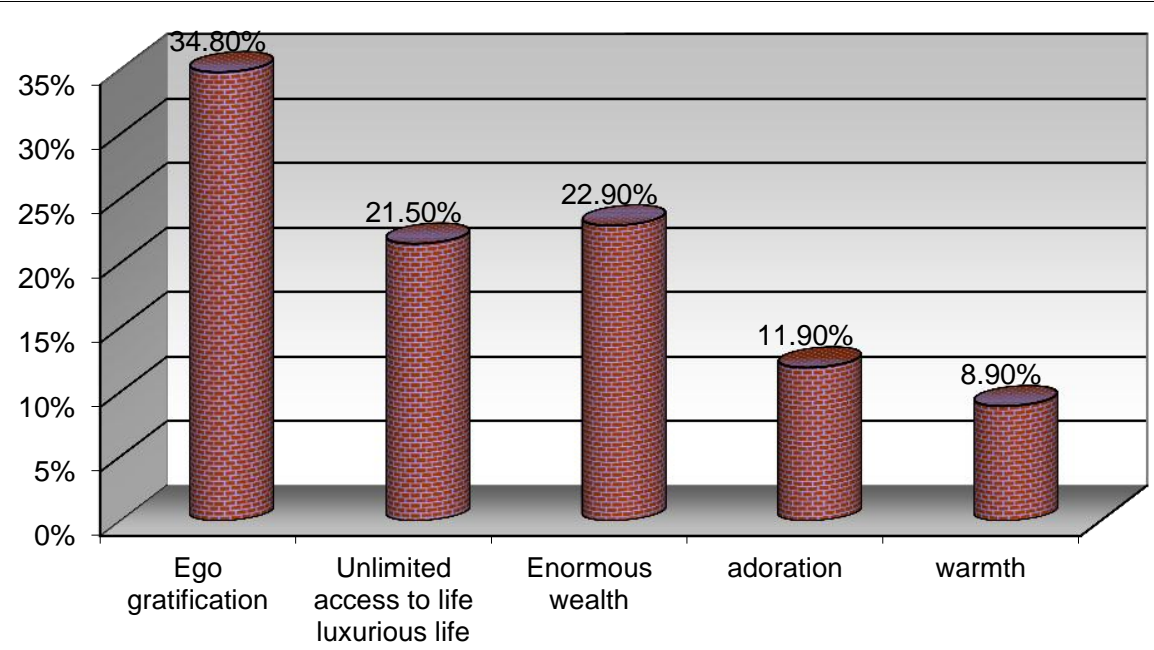

Figure (12) the distribution of the participants' according to parents' concepts about the experience of fame

As shown in table (12) and figure (12) Most of the participants $(n=47)$ reported that Ego gratification with a percentage $34.8 \%$, followed by 31 reported that Enormous wealth with a percentage $22.9 \%$. Then 29 of the participants reported that Unlimited access to life luxurious life with a percentage $21.5 \%$, while 16 of the research sample reported that Adoration with a percentage $11.9 \%$. Finally only 12 of the research sample reported that Warmth with a percentage $8.9 \%$. 
These findings showed that Ego gratification is the motivation that drives children to seek fame to satisfy their goals and ego, as the findings of the study of Young and Pinsky (2006) found that famous people attending a radio station for interview scored higher on the Narcissistic Personality Inventory (NPI) than scale norms for the general population.

\section{3- common child's behavioral problem of being famous which}

\section{the parent think affect the child negatively:}

Table (13) the distribution of the participants' according to child's behavioral problem of being famous which the parent think affect the child negatively

\begin{tabular}{|c||c|c|}
\hline $\begin{array}{c}\text { Which of the following common } \\
\text { child's behavioral problem of } \\
\text { being famous do you think effect } \\
\text { the child negatively }\end{array}$ & Number & Percentage \\
\hline \hline Abusive language & 11 & $8.1 \%$ \\
\hline Disrespect others & 18 & $13.3 \%$ \\
\hline Being bossy to others & 21 & $15.6 \%$ \\
\hline Violent behaviors & 28 & $20.7 \%$ \\
\hline Being bulling victim & 34 & $25.2 \%$ \\
\hline Lack of motivation and laziness & 23 & $17 \%$ \\
\hline \hline Sum & 135 & $100 \%$ \\
\hline
\end{tabular}




\section{الجمعية المصرية للقر اعة والمعرفة عضو الجمعية الدولية للمعرفة}

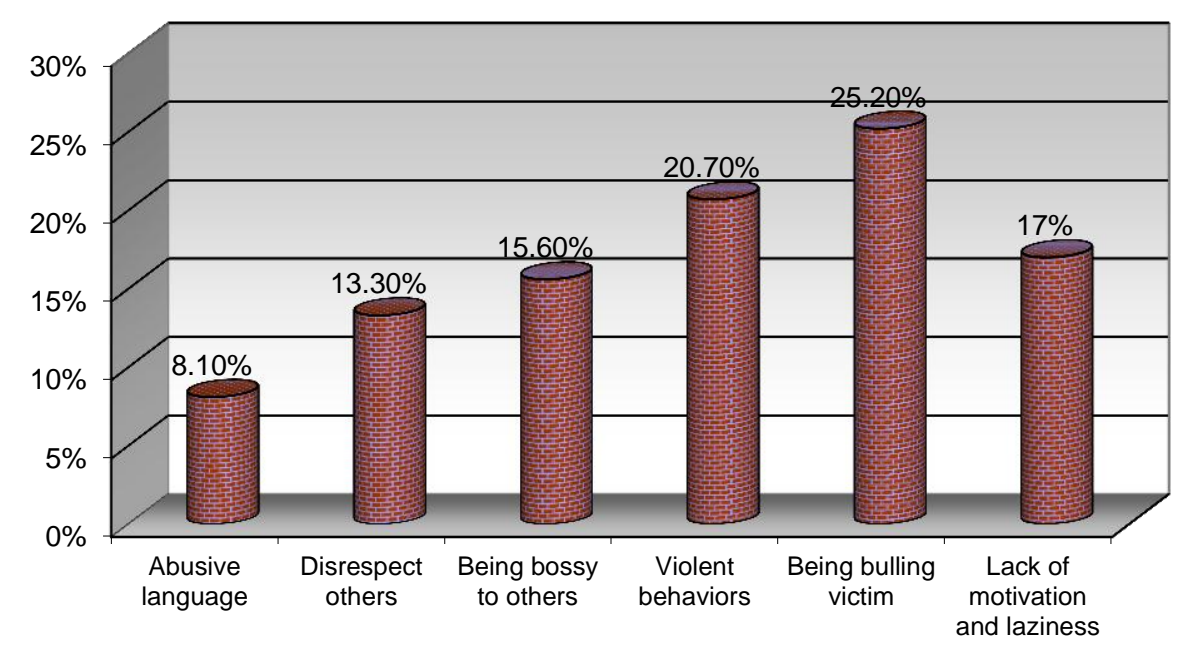

Figure (13) the distribution of the participants' according to child's behavioral problem of being famous which the parent thinks affect the child negatively

As shown in table (13) and figure (13) Most of the incidents $(n=34)$ were reported Being bulling victim with a percentage $25.2 \%$, followed by 28 reported that Violent behaviors with a percentage $20.7 \%$. Then 23 of the participants reported that $S$ Lack of motivation and laziness with a percentage $17 \%$, while 21 of the research sample reported that Being bossy to others with a percentage $15.6 \%$. Then in the fifth place 18 of the research sample reported that Disrespect others with a percentage $13.3 \%$, finally 11 of the research sample reported that Abusive language with a percentage $8.1 \%$.

These findings stated that most parents think the child being bulling victim is the main reason which drives the children seeking fame, as the study of Giles (2000) suggest self-esteem explanations for those who are famous, with those being particularly high in self-esteem, or those having particularly low selfesteem, seeking to be famous due to issues of confidence, be it under- or overconfidence of one's own self-image.

\section{References}

1. Amy Noser \& Virgil Zeigler-Hill (2014) Self-Esteem Instability and the Desire for Fame, Self and Identity, 13:6, 701-713, DOI: 10.1080/15298868.2014.927394 
2. Boyd (2009): Social media is here to stay... Now what? Microsoft Research Tech Fest.

3. Boyd, Danah m., \& Ellison, N. B. (2007): Social Network Sites: Definition, History, and Scholarship, Journal of Computer-Mediated Communication, 13(1), 210-230.

4. Braudy, L. (1997). The frenzy of renown: Fame and its history (2nd ed.), New York: Vintage.

5. Choi, C.J., and Berger, R. (2009): ethics of global internet, community and fame addiction, journal of business ethics, 85 .

6. Consumer Reports (2011): Five million Facebook users are 10 or younger, Retrieved from:

http://www.consumerreports.org/cro/news/2011/05/five-millionfacebook-users-are-10-or-younger/index.html

7. Dara N. Greenwood (2013): Fame, Facebook, Twitter: How Attitudes about Fame Predict Frequency and Nature of social media use, psychology of popular media culture, vol. 2, No. 4.

8. Dara Greenwood, long, sonya (2013): Fame and the social self: The need to belong, narcissism, and relatedness predict the appeal of fame, personality and individual differences 55 .

9. Foster, J. D., Campbell, W. K., \& Twenge, J. M. (2003). Individual differences in narcissism: Inflated self-views across the lifespan and around the world, Journal of Research in Personality.

10. Giles, D. (2000): Illusions of immortality: A psychology of fame and celebrity. London: Macmillan.

11. Giles, D. C., \& Maltby, J. (2004): The role of media in adolescent development: Relations between autonomy, attachment, and interest in celebrities, Personality and Individual Differences.

12. Gountas, J., Gountas, S., Reeves, R. A., \& Moran, L. (2012): Desire for fame: Scale development and association with personal goals and aspirations, Psychology and Marketing.

13. Greenberg, J., Kosloff, S., Solomon, S., Cohen, F. \& Landau, M. (2010): toward understanding the fame game: The effect of mortality salience on the appeal of fame, self and identity, 9.

14. Greenwood, D., Long, C., \& Dal Cin, S. (2013): Fame and the social self: The Need to belong, narcissism, and relatedness predict fame appeal, Personality and Individual Differences, doi:10.1016/j.paid.2013.04.020

15. Gunn, J. B., \& Donahue, E. H. (2008): Children and electronic media: Introducing the issue, 18(2), Princeton-Brookings. 
16. Halpern, J. (2007): Fame junkies: The hidden truths behind America's favorite addiction, New York: Houghton Mifflin.

17. Henrich, J., \& Gil-White, F. J. (2001): The evolution of prestige: Freely conferred deference as a mechanism for enhancing the benefits of cultural transmission, Evolution and Human Behavior.

18. Johnson, A.M., \& McSmith, A. (2006): Children say being famous is best thing in the world, Retrieved December 20, 2010 from http://news.independent.co.uk/uk/thisbritain/article2083906.ece.

19. Konrath, S. H., O’Brien, E. H., \& Hsing, C. (2011): Changes in dispositional empathy in American college students over time: A metaanalysis. Per- FAME, FACEBOOK, AND TWITTER 235 sonality and Social Psychology Review, 15, 180-198. doi:10.1177/1088868310377395

20. A. M. Kaplan and M. Haenlein (2010): Users of the world, unite!, The challenges and opportunities of social media, Business Horizons.

21. Maltby, J. (2010): An interest in fame: Confirming the measurement and empirical conceptualization of fame interest, British Journal of Psychology.

22. Maltby, J., Day, L., Giles, D. C., Gillett, R., Quick, M., LangcasterJames, H., et al. (2008): Implicit theories of a desire for fame, British Journal of Psychology, doi:10.1348/000712607X226935

23. Nadkarni, A., \& Hofmann, S. G. (2012). Why do people use Facebook? Personality and Individual Differences, doi:10.1016/j.paid.2011.11.007

24. Pattinson, G. (2008): Fireman, astronaut - or celebrity? From BBC News Online retrieved November 15, 2008, from http://news.bbc.co.uk/today/hi/today/newsid_7725000/7725217.stm

25. Rojek, Chris (2001): Celebrity, London: Reaction Books.

26. Subrahmanyam, K., \& Smahel, D. (2010): Digital youth: The role of media in development. New York, NY: Springer.

27. Toma, C. L., \& Hancock, J. T. (2013). Selfaffirmation underlies Facebook use. Personality and Social Psychology Bulletin, doi:10.1177/0146167212474694

28. Uhls, Y. T. \& Greenfield, P. M., (2012): The value of fame:

Preadolescent perceptions of popular media and their relationship to future aspirations, Developmental Psychology.

29. Vonk, R., \& Smit, H. (2012): Optimal self-esteem is contingent: Intrinsic versus extrinsic and upward versus downward contingencies, European Journal of Personality. 
30. Wilson, R. E., Gosling, S. D., \& Graham, L. T. (2012): A review of Facebook research in the social science, Perspectives on Psychological Science. http://dx.doi.org/10.1177/1745691612442

31. YouGov (2006): Young People and Reality TV, Retrieved June 22, 2007 , from page 1 at http://www.yougov.com/archives/pdf/BRO050101012_1.pdf

32. Young, S. M., \& Pinsky, D. (2006): Narcissism and celebrity. Journal of Research in Personality, 40, 463-471.

\section{آراء الآباء اتجاه شهرة الأطفال فى مواقع التواصل الاجتماعى

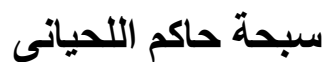 \\ قسم رياض الأطفال، جامعة أم القرى، المملكة العربية السعودية \\ ميساء يوسف مهندس}

قسم رياض الأطفال، جامعة أم القرى، المملكة العربية السعودية مليف

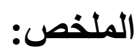

الخلفية: في السنوات الأخيرة ، أصبحت مواقع التواصل الاجتماعى في كل مكان ومهمة للتواصل

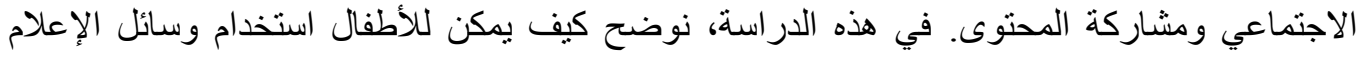

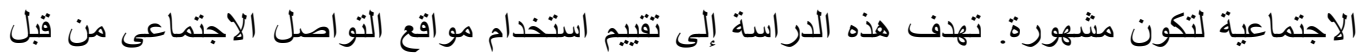

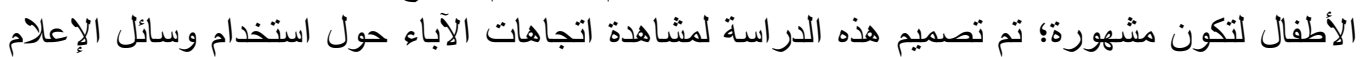

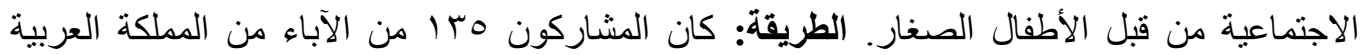

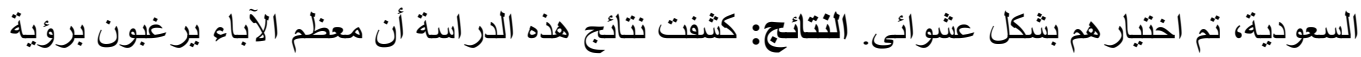

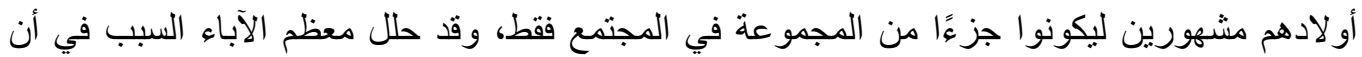

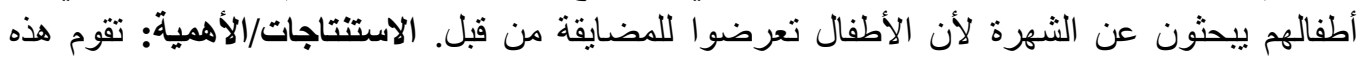

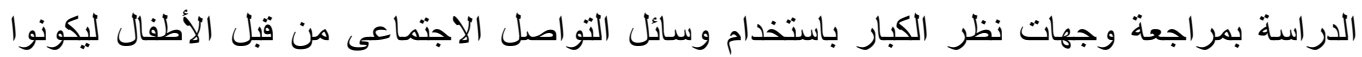

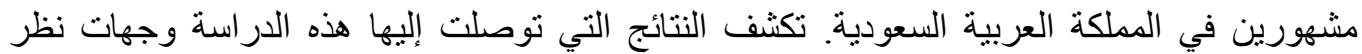

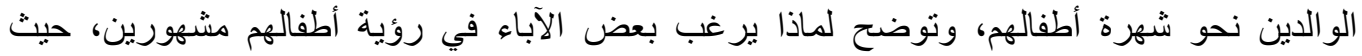

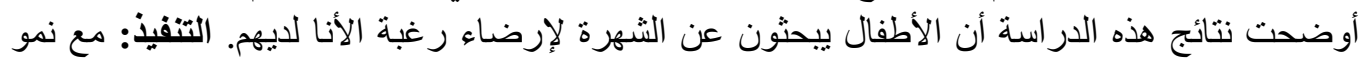

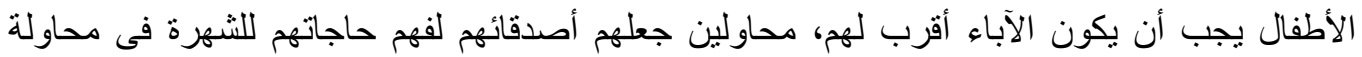
لأنقاذهم من الجرى ور اء شبح الثهرة. 